\title{
戦後沖縄文学と東アジア
}

一一暴力の感受性とマイノリテイの声

\author{
Jiyoun SON(孫知延: Associate Professor, KyungHee University Department of Japanese \\ and Director of Global Ryukyu Okinawa Institute) \\ 冈sonson@khu.ac.kr
}

(韓国) 慶熙大日本語学科副教授。グローバル琉球沖縄研究所長。主著に『戦後沖縄文学を考える方法一ジェン ダー・エスニック・ナショナルアイデンティティ』(ソウル：ソミョン出版、2020)、『越境する韓国文学史』(ソウル： ソミョン, $2020[$ 共著])、訳書に『大城立裕文学選集』(ソウル：グルヌリム、2018)、『沖縄と朝鮮のはざまで』(ソウ ル:ソミョン出版, 2019)など。

\section{Post-war Okinawa Literature and East Asia :The Impulse toward Anti-Violence and the Sensitivity to the Voices of Minorities}

This article aims to identify a way for scholars in the field of Okinawa studies working in Korea and Japan to share their research results and to expand Okinawa research further afield in East Asia through future exchanges and collaboration . To this end, this paper will firstly introduce a research project that is being carried out in Korea on the theme of <Post-war Okinawan Literature and the East Asian Impulse toward Anti-violence and Sensitivity to the Voices of Minorities>. This is a general joint research project which received support from the National Research Foundation of Korea in July 2019, and which is being carried out over the course of two years, from 2019 to 2021.

The research team is composed of Korean and Japanese Literature majors, and the scope of the research encompasses research results related to Okinawa. The aim of this project is to bring into clearer view the circumstances of the entirety of East Asia, which was in the midst of post-war imperialist violence, from Okinawa and Korea (Jeju 4.3 Literature) to Taiwan, Vietnam and the South Sea Islands, with an additional focus on the situation of the Korean-Japanese community in Japan.

Keywords Post-war Okinawa Literature(戦後沖縄文学), East Asia(東 アジア), Impulse toward Anti-violence(反暴力の感受性), Voices of Minorities(マイノリティの声) 


\section{1 はじめに}

本稿は韓国と日本で活動する沖縄関連の研究者が、お互いの研究成果を共有 し、今後の交流及び協業を通じて、沖縄研究を東アジアの地平にまで広げていく 道を模索することにその目的がある。そのためにまず、韓国において進められ ている沖縄研究の流れを紹介することとする。〈戦後沖縄文学と東アジア-反暴力 の感受性とマイノリティの声〉(NRF-2019S1A5A2A03034606)というテーマの研 究がそれなのだが、この研究は、2019年7月に韓国研究財団の一般共同研究の課 題に選定され、2019年より2021年までの2年間にわたって遂行される予定であ る。

研究陣は韓国文学、日本文学の専攻者によって構成されており、これまでの 沖縄関連研究の成果をさらに拡張し、沖縄をはじめ韓国(済州)、台湾、べトナ ム、南洋諸島、そして在日朝鮮人社会にいたるまで、帝国主義の暴力の中に立た されてきた東アジア全般を視野に入れている。

その具体的な研究方法論として、「反暴力」と「マイノリテイ」という概念を積 極的に活用しようと考えた。前者は、沖縄文学の暴力性を感知する感受性と、そ れを批判する知的想像力を探索するものであり、後者は、沖縄文学のマイノリ ティ性についての探求である。ここでのマイノリティ性というのは、帝国主義 に立ち向から自己存在の証明様式であり、帝国の秩序が構築してきた世界秩序の 限界を内破し、新たな世界文学の可能性を打診する積極的かつ能動的な概念とし て用いようと考えた。この研究は、日常が戦場化するという現実や、日常に内在 する暴力に立ち向からという抵抗が果たして可能なのかを問う冨山一郎のような 思惟であったり、沖縄、アイヌ、台湾、朝鮮などの近代日本の境界領域に注目 し、日本人のナショナルアイデンティティを掘り返した小熊英二やイム・チョ ンチュン(林泉忠)、テッサ・モーリス鈴木のような思惟と相接していながらも弁 別されている。要するに、戦争と日本帝国の暴力性に対する鋭い観点を示した冨 山一郎や小熊英二の議論には、韓国の済州 4 ・3、光州 5 ・ 18、また台湾の $2 \cdot 28$ と いったような文脈が完全に抜け落ちているのだが、本研究ではこのような側面 にも留意し、文学的想像力を通して、それをできる限り具体的に捉えようとし た。何より、韓国文学、日本文学の下位文学としての済州文学、沖緡文学、ある いは在日朝鮮人文学を掘り起こすということではなく、台湾、ベトナム、南洋諸 島などの東アジア文学におけるローカル的想像力と対比し、また結び付け、こ れらマイノリティの叙事的応戦の複雑な様相を鮮明に浮彫りにするというとこ ろに、本研究の独創性及び斬新さが見いだせるものと思われる。 


\section{2 沖縄文学認識の外縁拡張}

沖縄文学の大きな特徵の一つとして、暴力性を感知する感受性と、これを批 判する知的想像力をあげることができる。琉球王国は日本の植民地に転落する前 は、中国や日本の間で、東アジア海上交流の一部領域を占めており、比較的平和 な暮らしを持続させていた。しかし、日本の植民地となってからは、急速に暴 カのるつぼへと陥った。

日本の帝国主義的近代性が示した同化と融和へと急速に編入されゆく中で、自 己の言語とアイデンティティを失ってしまった。一方では日本人に同化し、ま た一方では、日本人ではなく沖縄人であるという自意識を持つというようなア イデンティティの危機に直面した。その頂点が、沖縄戦でのいわゆる集団自決 と呼ばれる強制集団死である。強制集団死を経験し、自分たちは日本人ではない かもしれない、という内面的な省察をするようになる。日本帝国が沖縄人たち に加えたこの暴力は、その後の住民たちに消すことのできない傷を負わせたた め、沖縄の作家たちは、この問題から目をそらすことができなかった。このよ うな暴力性は、その後の米軍基地問題へと続き、今日まで続いている。日本から 沖縄を受け継いだ後、アメリカは沖縄をアメリカの対東アジア支配の前哨基地と した。ベトナム住民が沖縄を「悪魔の島」と呼んだように、沖縄はアメリカのべ トナム侵攻の基地となり、沖縄は自分たちの意思に反し、他国を侵略する役割を 担うことになったのである。アメリカの対東アジア支配の一つの要因として作 用していた自分たちの運命を、沖縄の作家たちは見逃さず、これを再現し、そ の過程において暴力性に対する批判は、核心的な主題として浮上した。沖縄が日 本の領域に移ると、この米軍基地の問題は、一層複合的に進んでいった。安保闘 争以後、日本本土においてこれ以上、米軍基地の存立が困難になるや、日本政府 は沖縄をその犠牲とした。既存の本土の米軍基地を沖縄に移転、あるいは新たに 米軍基地を新設するという方法をとって、沖縄は米軍基地の土地となっていっ た。今日の日本は、沖縄の犠牲の上に成り立っているという見解が妥当性を有し ているというのは、すなわちこのような理由からなのである。普天間基地の辺 野古への移転に反対し、アメリカの領土へ移せと叫ぶ沖縄人の内面には、帝国の 暴力性に対する強い批判が込められている。アメリカの東アジア支配及び日本の 東アジア覇権維持の犠牲となっている沖縄のこの暴力的な現実から、沖縄の文学 家たちは目をそらさなかった。又吉栄喜、大城貞俊、目取真俊の作品の中に、強 制集団死や米軍基地を扱った作品が多く見られるのは、そのような点からしても 極めて自然であるといえる。沖縄文学が世界性を獲得しているのは、まさにこ のような暴力性を日常において再現できるという条件と能力からである。

このような暴力性の再現問題とともに、本研究が注目しているもう一つの側 
面が、韓国文学と沖縄文学のマイノリティ性である。韓国文学と沖縄文学のマイ ノリティ性は、帝国主義に対する抵抗と包摂、協力と抵抗という線分の中で誕生 した。従って、韓国において沖縄文学を研究するということは、沖縄文学のマ イノリティ性が形成されてきた過程を理解すると同時に、韓国文学の普遍性を探 求する作業でもある。東アジアの近代が、帝国の暴力性に立ち向かう自己存在の 証明様式であるとした時、このようなマイノリティ性に対する探求は、帝国の 秩序が構築してきた世界秩序の限界を内破し、新たな世界文学の可能性を打診す るという意味があるといえよう。

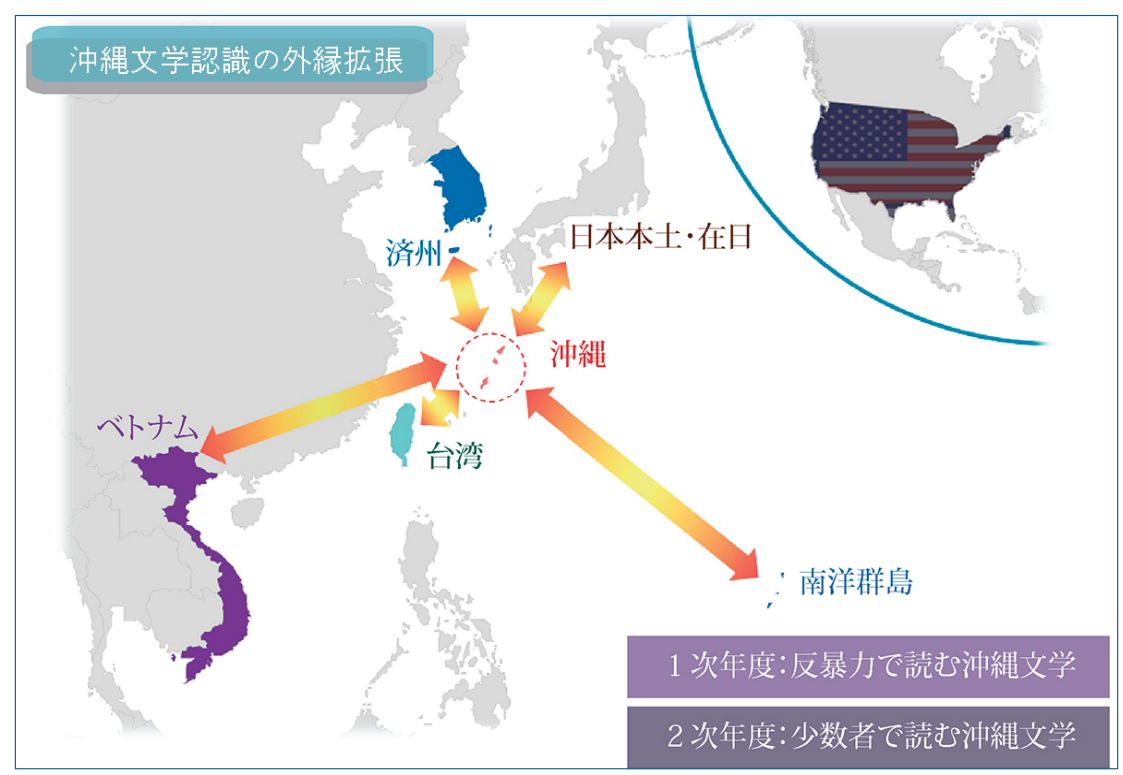

\section{3「反暴力」と「マイノリティ」という概念}

沖縄文学は、沖縄内部に存在する多様な他者を通じて、日本とアメリカ(米軍) がふるってきた暴力のシステムを露呈させ、さらには日本が構築した暴力のシ ステムを積極的に遂行し、黙認した沖縄の態度を、極めて具体的かつ持続的に描 いてきた。また「日本での唯一の地上戦」、鉄の暴風」などという修飾語によっ て隠された沖縄の加害性は、沖縄内部に存在する様々な立場の他者、換言するな ら階級や人種、ジェンダーなどにおける複雑かつ重層的な他者によって発見さ れ、沖縄の戦後思想を省察するよう促している。韓国文学もやはり植民地主義と 冷戦体制を経て、近代の暴力性に対して鋭敏な感受性を露呈してきた。東アジア 文学における「反暴力」の様相を、韓国 (済州) ・沖縄文学との比較で見るという研 
究の必要性は、まさにここにあるといえよう。

このように、韓国(済州)と沖縄文学のマイノリティ性を究明するための共通 分母として「反暴力」という概念を用いたのであれば、東アジア文学の中心主義的 位階を越える対応方式を省察するための方法論としては、「マイノリティ」の概念 を用いることとした。

沖縄は日本の地域の一部ではあるが、他の地域や県とは異なった特殊性を 持っている。他の地域もやはり各自の地域性を強調はするが、日本からの独立を 主張することはない。また、行政的には現在の日本の一つの県として属してい るが、県民の中には自分が日本人であると自覚している人もいれば、日本人では なく沖縄人、あるいは琉球人として生きることを望んでいる人々も少なからず 存在する。近年では、後者として自分のアイデンティティを見いだそうとする 住民が徐々に増えてきており、特に知識人の中には、沖縄の独立を主張する人久 が徐々に増えてきている。このような点において、マイノリティとしての沖縄 人には、単に地域的な特性を強調するにとどまらず、独立した国民国家を思い描 いているマイノリティであるという特徴がある。

従って、沖縄文学を探求するにあたって、国民文学が語らない地域文学の想 像力を、こと細かに読み込む必要がある。その一端として、本研究では、「マイ ノリティ」の概念を積極的に解釈していくこととした。「マイノリティ」を支配的 かつ多数的な秩序から抜け出た存在であると規定するのは、日本帝国秩序の中 で、日本-沖縄、沖縄-朝鮮という二重の抑圧を理解するためである。特に、沖縄 内部の位階、例えば沖縄本島と八重山諸島との間の内部植民地的関係を考察する ために「マイノリティ」の概念を積極的に活用するのである。マイノリティの概 念を導入することにより、韓国文学のマイノリティ性においてもやはり、一国 の次元でのマイノリティではない、ソウル-地方という中央中心主義的な文学的 位階が胚胎しているマイノリティの多様な導出様式を考察することが可能であろ う。

\begin{tabular}{|c|l|}
\hline \multicolumn{2}{|c|}{ 「反暴力」で語む沖縄文学 } \\
\hline テーマ1 & 国家暴力の戦後的記憶あるいは忘却 \\
\hline テーマ2 & 反暴力の方法 \\
\hline テーマ3 & 沖縄とベトナムの「驚異的な現実」その反暴力の世界 \\
\hline テーマ4 & 躍動する島の想像力 \\
\hline テーマ5 & 沖縄文学と在日朝鮮人文学に現れた「反暴力」問題 \\
\hline テーマ6 & 金廷漢の小説に現れた「南洋諸島」の帝国主義と暴力の様相 \\
\hline テーマ7 & 内部植民地の誕生と反暴力の様相 \\
\hline
\end{tabular}




\begin{tabular}{|c|l|}
\hline \multicolumn{2}{|c|}{ 「マイリティ」で読む沖縄文学 } \\
\hline テーマ1 & マイノリティの身体と反国家的想像力 \\
\hline テーマ2 & 日本の南洋諸島統治と朝鮮/沖縄のマイノリティの表象 \\
\hline テーマ3 & 「証言文学」の観点で読む東アジアのマイノリティ \\
\hline テーマ4 & 沖縄戦小説と4.3小説に現れた共同体自立言説の対比的考察 \\
\hline テーマ5 & 人類普遍の戦闘とマイノリティ文学の可能性としての沖縄文学 \\
\hline テーマ6 & 植民地時代末期における東アジア地域のマイノリティとしての朝鮮 \\
\hline 人の現実と東アジア的連带 \\
\hline テーマ7 & 反逆的身体の誕生とマイノリティの声 \\
\hline
\end{tabular}

〈グローバル琉球沖縄研究所 : http://ccs.khu.ac.kr/project2/content1〉

\section{4 現在までの研究成果、そして今後の計画}

現在、1年次の課題のしめくくり段階にある。1年次の主題である「『反暴力』で 読む沖縄文学」を通じて、沖縄内部に存在する多様な他者が発信する叙事的な声 を、多様なテキストを通じて確認することができた。文学テキストのみなら ず、沖縄、そして韓国において発行されたメディア資料では、沖縄が韓国とい う他者を「発見」する方法、あるいは韓国が沖縄を呼名する方法の同時性と落差を 見ることができた。何よりも、沖縄と韓国が、植民地主義と冷戦体制という東ア ジアの時空間を共有し、国家暴力に対する抵抗的な叙事の可能性に注目した研究 方法論を共有しうることを確認できた。すなわち、文学テキストに限らず、沖 縄と韓国が植民地主義と冷戦体制の中で、お互いを発見する方法、そして淵源を 想像する方法に注目し、「沖縄学」という作られた表象がどのように再構築されて いったのかを、東アジアという枠組みの中で思惟するに至ったのは、本研究 チームの注目すべき研究成果であるといえる。

その中でいくつか研究成果をあげると、国際学術大会、深層的研究のための 専門家招請による対談会及びコロキウムを積極的に行い、研究者間の緊密なネッ トワークを構築すると同時に、研究テーマと関連した有意義な議論の場を設けて きたことなどがある。また、研究者間の交流にとどまらず、沖縄現地作家及び評 論家とのコミュニケーションにも積極的に取り組んだ。東京や沖縄への出張で は、大城立裕、又吉栄喜、目取真俊、崎山多美、大城貞俊といった沖縄文学を代 表する作家と交流し、評論家として広く知られている仲里効をはじめ新城郁夫、 戸邊秀明、佐藤泉といった少壮学者との深い学問的交流を行ってきた。1年次だ けでも、韓国と沖縄を往来しながら、二度の国際学術大会と、三度の作家との対 談会及び二度のインタビューを成功裏に終えることができた。これらは当初の 計画を上回る成果である。 
また、当初、研究チームにおいて計画していた個別論文の執筆以外に、責任 研究者及び博士級専任研究員の共同論文の執筆という研究成果も加えることがで きた。文学の地平を社会、経済、文化の領域にまで拡張することにより、韓国 (済州) と沖縄がどのように出会うか、これまでとは異なった新たな分析の枠組み を確保することができた。その他にも、近現代沖縄の思想史をまとめた編訳書の 草稿も完成した状態である。本の末尾にも、東京で行われた戦後沖縄思想に関す る戸邊秀明教授(東京経済大学)へのインタビュ一内容を載せて、読者の理解をサ ポートしている。

まもなく始まる2年次の研究「『マイノリティ』で読む沖縄文学」では、近年沖縄 の知識人の間で沖縄の独立を主張する声が台頭しているなど、マイノリティと しての沖縄、沖縄人の多様な主義主張が噴出しているのだが、そのような流れを 東アジアとの関連性の中で深く見ていきたいと考えている。

最後に、韓国と沖縄という個別地域を越えた東アジア文学の豊かな想像力、 連帯の可能性が、本研究課題の後続研究を通じて一層充実していくことを期待し ている。 